\title{
Peranan Aspek Lingkungan dalam Manajemen Aset Infrastruktur \& Fasilitas
}

\author{
Role of Environmental Aspects in Infrastructure \& Facility Asset \\ Management
}

\author{
Mohammad Razif ${ }^{1, a)}$ \\ ${ }^{1)}$ Jurusan Teknik Lingkungan, Institut Teknologi Adhi Tama Surabaya (ITATS), Surabaya. \\ Koresponden : ${ }^{a)}$ razif@itats.ac.id
}

\begin{abstract}
ABSTRAK
Tujuan penelitian ini adalah untuk memahami peranan aspek lingkungan dalam Manjemen Aset Infrastruktur, penelitian ini dilakukan dengan menguraikan pengertian aspek dan dampak lingkungan, jenis kegiatan pembangunan dan pengoperasian infrastruktur beserta fasilitasnya yang menimbulkan dampak lingkungan. Suatu aspek lingkungan hidup penting adalah aspek lingkungan hidup yang memiliki satu atau lebih dampak lingkungan hidup penting. Dampak lingkungan hidup sendiri diartikan perubahan pada lingkungan, baik yang merugikan atau menguntungkan keseluruhan atau sebagian disebabkan oleh aspek lingkungan suatu organisasi. Kegiatan manajemen aset infrastruktur dan fasilitasnya merupakan kegiatan yang secara umum menimbulkan dampak lingkungan sehingga perlu menyusun amdal atau UKL-UPL sesuai dengan penting atau tidaknya dampak lingkungan yang akan ditimbulkannya. Untuk kegiatan manajemen aset infrastruktur dan fasilitasnya yang sudah dan sedang beroperasi tapi belum memiliki izin lingkungan, masih perlu menyusun DELH (Dokumen Evaluasi Lingkungan Hidup) atau DPLH (Dokumen Pengelolaan Lingkungan Hidup) sesuai dengan penting tidaknya dampak lingkungan yang sudah dan sedang berlangsung. Pelaksanan dokumen amdal, UKL-UPL, DELH, DPLH perlu dilaporkan dengan membuat pelaporan setiap 6 bulan sekali ke Dinas Lingkungan Hidup di Kabupaten/Kota/Propinsi atau ke Kementerian Lingkungan Hidup disesuaikan dengan kewenangannya masing-masing.
\end{abstract}

Kata Kunci : manajemen aset infrastruktur \& fasilitas, aspek lingkungan, dampak lingkungan, RKL, RPL.

\section{PENDAHULUAN}

Infrastruktur dan Fasilitas merupakan Prasyarat Dasar bagi Pembangunan dan Pertumbuhan. Keduanya bukan obyek sederhana dan membutuhkan biaya yang sangat besar. Selain itu, keterkaitan keduanya dengan Aspek Lingkungan sangat penting. Oleh karena itu keduanya harus dikelola dengan benar sesuai dengan prinsip Manajemen Aset Infrastruktur \& Fasilitas (Soemitro \& Suprayitno 2018; Suprayitno \& Soemitro 2018). Uraian mengenai keharusan unutk dikenakan Analisi Dampak Lingkungan bagi Infrastruktur \& Fasilitas dengan Lingkungan belum dibahas secara cukup dalam JMAIF. Oleh karena itu diperlukan uraian mengenai hal tersebut.

Analisis mengenai dampak lingkungan hidup (amdal) adalah metode ilmiah dari ilmu lingkungan yang multi disiplin dan telah dikembangkan oleh Kementerian Lingkungan Hidup dan banyak Perguruan Tinggi di Indonesia untuk dapat mengevaluasi besar dan pentingnya dampak lingkungan yang disebabkan oleh aktifitas pembangunan di segala sektor, termasuk 
sektor pembangunan infrastruktur dan fasilitasnya. Berdasarkan hasil evaluasi dampak ini setiap pemrakarsa rencana kegiatan dapat membandingkan secara ekonomi berapa besarnya upaya mengelola dan memantau dampak lingkungan hidup (biaya RKL dan RPL) dengan manfaat yang akan diperoleh dari kegiatan proyek. Jika manfaat (benefit) dari kegiatan proyek lebih kecil dari biaya (cost) untuk mengelola dan memantau dampak lingkungan hidup, maka proyek infrastruktur dan fasilitasnya sebaiknya seawal mungkin dinyatakan tidak layak lingkungan dan tidak mendapat izin lingkungan, sehingga tidak perlu dibangun, dan hal ini berlaku sebaliknya. Dampak lingkungan hidup dari kegiatan pembangunan infrastruktur dan fasilitasnya saat ini sudah sangat mudah diprakirakan besarnya dengan berbagai metode prakiraan dampak baik secara formal maupun informal (Fandeli, 2000). Misalnya secara informal bisa diprakirakan besarnya dampak dengan melakukan analogi pada proyek sejenis yang sudah dibangun, meskipun tidak selalu tepat karena adanya perbedaan rona lingkungan antar lokasi proyek yang akan menghasilkan dampak yang berbeda. Dampak yang umumnya terjadi adalah timbulnya pencemaran terhadap media lingkungan seperti pencemaran air, pencemaran udara, pencemaran tanah dan dampak pada kegiatan sosial, ekonomi dan budaya. Peraturan Menteri Lingkungan Hidup 13/2011 (Anonim, 2011) sangat membantu pemrakarsa kegiatan atau konsultan amdal untuk menghitung kerugian akibat pencemaran atau kerusakan lingkungan. Media lingkungan yang terkena dampak bisa dalam skala kecil sampai besar. Sebagai contoh pembangunan jalan raya antar kabupaten atau antar propinsi di Sumatra dan Kalimantan bisa berdampak kerusakan pada ekosistem gambut. Demikian pula pembangunan jalan raya, bandara, atau bendungan di Sulawesi dan Papua bisa berdampak kerusakan pada ekosistem hutan yang dibebaskan untuk keperluan infrastruktur dan fasilitasnya. Dengan mengelola dan memantau dampak yang ditimbulkan akibat pembangunan infrastruktur dan fasilitasnya, maka pengoperasian infrastruktur dan fasilitas dapat mengikuti konsep strategi pembangunan yang berkelanjutan (Yakin, 1997; Alshuwaikhat, 2005; Jay S.et al, 2007).

\section{METODE PENELITIAN}

Karena tujuan penelitian ini adalah untuk memahami peranan aspek lingkungan dalam Manjemen Aset Infrastruktur, penelitian ini dilakukan dengan menguraikan pengertian aspek dan dampak lingkungan, jenis kegiatan pembangunan dan pengoperasian infrastruktur beserta fasilitasnya yang menimbulkan dampak lingkungan yang akan ditimbulkan oleh pembangunan dan serta rencana pengelolaan dan pemantauan dampak yang perlu disusun untuk mengantisipasi dampak lingkungan yang akan terjadi.

\section{TINJAUAN PUSTAKA}

\section{Pengertian aspek dan dampak lingkungan hidup}

Menurut definisi SNI ISO 14001 (BSN, 2015), aspek lingkungan hidup adalah unsur kegiatan atau produk atau jasa dari organisasi yang berinteraksi atau dapat berinteraksi dengan lingkungan. Suatu aspek lingkungan penting adalah aspek lingkungan yang memiliki satu atau lebih dampak lingkungan penting. Dampak lingkungan sendiri diartikan perubahan pada lingkungan, baik yang merugikan atau menguntungkan keseluruhan atau sebagian disebabkan oleh aspek lingkungan suatu organisasi.

Menurut Undang-undang 32/2009 (Anonim, 2009), lingkungan hidup adalah kesatuan ruang dengan semua benda, daya, keadaan, dan makhluk hidup, termasuk manusia. Dampak lingkungan hidup adalah pengaruh perubahan pada lingkungan hidup yang diakibatkan oleh suatu rencana usaha dan/atau kegiatan. Analisis mengenai dampak lingkungan hidup (amdal), adalah kajian mengenai dampak penting suatu rencana usaha dan/atau kegiatan yang direncanakan pada lingkungan hidup yang diperlukan bagi proses pengambilan keputusan tentang penyelenggaraan usaha dan/atau kegiatan. Sedangkan upaya pengelolaan lingkungan 
hidup dan upaya pemantauan lingkungan hidup (UKL-UPL) adalah pengelolaan dan pemantauan lingkungan hidup terhadap usaha dan/atau kegiatan yang tidak berdampak penting terhadap lingkungan hidup yang diperlukan bagi proses pengambilan keputusan tentang penyelenggaraan usaha dan/atau kegiatan.

Dalam penyusunan amdal ini tim studi perlu melibatkan masyarakat dan kegiatan ini dapat dilakukan melalui pengumuman lewat media seperti koran, radio dan sebagainya dan melalui tatap muka dalam acara konsultasi publik. Hasil pelibatan masyarakat akan menjadi input untuk proses pelingkupan yang merupakan fase penting dalam studi amdal (Momtaz S., 2002). Prosedur pelibatan masyarakat dalam proses amdal harus mengacu pada peraturan perundang-undangan seperti Peraturan Pemerintah 27/2012 (Anonim, 2012a) dan Peraturan Menteri Lingkungan Hidup 17/2012 (Anonim, 2012d). Tidak semua proses partisipasi masyarakat dalam amdal berjalan sempurna, Toro J. et.al (2009) menulis bahwa di Kolombia, partisipasi masyarakat dalam proses amdal sangat diskriminatif karena konsultasi hanya untuk penduduk asli, jika proyek itu memang secara langsung mempengaruhi wilayah di mana mereka tinggal. Sisa penduduk lainnya, partisipasinya berkurang sehingga tidak memperoleh informasi yang lengkap tentang rencana proyek. Partisipasi masyarakat yang tidak efektif ditemui di Pakistan (Nadeem O \& Hameed R., 2008) dan di Amerika peningkatan partisipasi tidak menjamin hasil yang lebih baik dalam pengelolaan lingkungan (Hourdequin M. et al, 2011). Penguatan prosedur partisipasi masyarakat dijumpai di Inggris dengan penerapan dalam bentuk konvensi (Hartley \& Wood, 2005). Di Indonesia proses partisipasi masyarakat dalam amdal juga belum berjalan sempurna. Sesuai dengan ketentuan dalam Peraturan Menteri Lingkungan Hidup 17/2012 (Anonim, 2012d) tidak semua masyarakat terkena dampak dilibatkan dalam sosialisasi dan konsultasi publik, pelibatannya melewati mekanisme perwakilan. Dalam sidang komisi penilai amdalpun masyarakat yang terkena dampak hadir lewat mekanisme perwakilan (masyarakat menunjuk wakil yang akan mengikuti sidang komisi penilai amdal). O'Faircheallaigh C (2009) berargumen bahwa model partisipasi masyarakat perlu juga memperhatikan bahwa interaksi yang terjadi dapat dalam bentuk yang berbeda-beda, dan fakta bahwa partisipasi masyarakat menimbulkan isu mengenai kendali atas pengambilan keputusan yang umumnya tidak tunduk pada resolusi, tetapi harus dikelola melalui proses perundingan (negosiasi). Di Indonesia prosesnya hampir sama, umumnya masyarakat yang terkena dampak menunjuk wakil-wakil mereka dalam tim yang akan bernegosiasi dengan pihak pemrakarsa untuk proses kompensasi, pemanfaatan tenaga kerja lokal, program-program CSR (corporate social responsibility) dan sebagainya. Peningkatan partisipasi masyarakat ini di negara berkembang memang perlu di tingkatkan dari waktu ke waktu (Jarvis \& Younger, 2000; Saarikoski, 2000; Opoku, 2001).

\section{Jenis Kegiatan yang menimbulkan dampak lingkungan}

\section{a. Kegiatan yang masih tahap perencanaan (belum berlangsung)}

Suprayitno dan Soemitro (2018) memberi 4 contoh infrastruktur, yaitu dam, road, solid waste yard, dan low cost rental aparment, sedangkan menurut Peraturan Menteri Lingkugan Hidup 5/2012 (Anonim, 2012b) ada cukup banyak kelompok infrastruktur dan fasilitas yang masuk kategori wajib amdal beserta alasan ilmiah khusus, seperti yang sudah diringkaskan di Tabel 1. 
Tabel 1. Jenis Kegiatan Yang Wajib Amdal beserta alasan ilmiah khususnya

\begin{tabular}{|c|c|c|c|}
\hline No & Jenis Kegiatan & $\begin{array}{l}\text { Skala/ } \\
\text { Besaran }\end{array}$ & Alasan Ilmiah Khusus \\
\hline 1 & $\begin{array}{l}\text { Pembangunan jalur kereta api } \\
\text { dengan atau tanpa stasiunnya } \\
\text { a. Pada permukaan tanah } \\
\text { b. Dibawah permukaan tanah } \\
\text { c. Diatas permukaan tanah }\end{array}$ & $\begin{array}{l}>25 \mathrm{~km} \\
\text { Semua } \\
\text { besaran } \\
>5 \mathrm{~km}\end{array}$ & $\begin{array}{l}\text { Berpotensi dampak emisi, gangguan lalu } \\
\text { lintas, kebisingan, getaran, gangguan } \\
\text { pandangan, ekologis, dampak sosial, } \\
\text { gangguan jaringan gas, listrik, air minum, } \\
\text { telkom, perubahan kestabilan tanah, land } \\
\text { subsidence dan air tanah }\end{array}$ \\
\hline 2 & $\begin{array}{l}\text { Pembangunan terminal } \\
\text { penumpang dan terminal barang } \\
\text { transportasi jalan }\end{array}$ & $>5 \mathrm{ha}$ & $\begin{array}{l}\text { Berpotensi dampak emisi, gangguan lalu } \\
\text { lintas, kebisingan, pencemaran udara, } \\
\text { getaran, tata ruang dan dampak sosial }\end{array}$ \\
\hline 3 & $\begin{array}{l}\text { Pembangunan pelabuhan } \\
\text { dengan salah satu fasilitas: } \\
\text { a. Demaga dengan konstruksi } \\
\text { sheet pile atau open pile } \\
\text { Panjang } \\
\text { Luas } \\
\text { b. Dermaga dengan konstruksi } \\
\text { massif }\end{array}$ & $\begin{array}{l}>200 \mathrm{~m} \\
>6000 \mathrm{~m}^{2} \\
\text { Semua } \\
\text { besaran }\end{array}$ & $\begin{array}{l}\text { a. Berpotensi dampak perubahan arus pantai } \\
\text { / pendangkalan dan sistem hidrologi, } \\
\text { ekosistem, kebisingan, mengganggu } \\
\text { proses alamiah di daerah pantai (coastal } \\
\text { processes) } \\
\text { b. Berpotensi dampak terhadap ekosistem, } \\
\text { hidrologi, garis pantai dan batimetri, } \\
\text { mengganggu proses alamiah yang terjadi } \\
\text { di derah pantai } \\
\text { c. Berpotensi dampak emisi, gangguan lalu } \\
\text { lintas, aksesbilitas transportasi, } \\
\text { kebisingan, getaran, gangguan } \\
\text { pandangan, ekologis, sosial dan } \\
\text { keamanan } \\
\text { d. Berpotensi dampak gangguan alur } \\
\text { pelayaran, perubahan batimetri, } \\
\text { ekosistem, mengganggu proses alamiah di } \\
\text { daerah pantai, saat bongkar muat minyak } \\
\text { mentah menimbulkan pencemaran laut } \\
\text { dari tumpahan minyak }\end{array}$ \\
\hline 4. & $\begin{array}{l}\text { Pembangunan Bandar udara } \\
\text { untuk fixed wing beserta } \\
\text { fasilitasnya }\end{array}$ & $\begin{array}{l}\text { Semua } \\
\text { pembangunan } \\
\text { Bandar udara } \\
\text { beserta hasil } \\
\text { studi rencana } \\
\text { induk yang } \\
\text { telah disetujui } \\
>1.200 \mathrm{~m} \\
>10.000 \mathrm{~m} 2\end{array}$ & $\begin{array}{l}\text { Berpotensi menimbulkan dampak berupa } \\
\text { kebisingan, getaran, dampak sosial, } \\
\text { keamanan negara, emisi dan kemungkinan } \\
\text { bangkitan transportasi baik darat maupun } \\
\text { udara, menimbulkan dampak sosial, dampak } \\
\text { potensial berupa limbah padat, limbah cair, } \\
\text { udara dan bau yang dapat mengganggu } \\
\text { kesehatan, mengubah bentuk lahan dan } \\
\text { bentang alam }\end{array}$ \\
\hline
\end{tabular}




\begin{tabular}{|c|c|c|c|}
\hline No & Jenis Kegiatan & $\begin{array}{l}\text { Skala/ } \\
\text { Besaran } \\
\end{array}$ & Alasan Ilmiah Khusus \\
\hline 5 & $\begin{array}{l}\text { Pembangunan Bendungan/ } \\
\text { Waduk atau Jenis Tampungan } \\
\text { Air lainnya } \\
\text { 1. tinggi; atau } \\
\text { 2. daya tampung waduk, atau } \\
\text { 3. luas genangan }\end{array}$ & $\begin{array}{l}>15 \mathrm{~m} \\
>500.000 \mathrm{~m} 3 \\
>200 \mathrm{ha}\end{array}$ & $\begin{array}{l}\text { Berpotensi menimbulkan dampak jika } \\
\text { terjadi failure maka akan menimbulkan } \\
\text { bencana banjir, } \\
\text { kegagalan bendungan pada daya tampung } \geq \\
500.000 \mathrm{~m} 3 \text {, } \\
\text { pengadaan tanah tapak bendungan dan } \\
\text { daerah genangan waduk memerlukan } \\
\text { pembebasan kawasan relatif luas dan } \\
\text { menyangkut kehidupan penduduk dan } \\
\text { ekosistem, mempengaruhi pola iklim mikro } \\
\text { kawasan disekitarnya dan ekosistem hulu } \\
\text { dan hilir bendungan/ waduk }\end{array}$ \\
\hline 6 & $\begin{array}{l}\text { Daerah Irigasi } \\
\text { a. pembangunan baru dengan } \\
\text { luas }\end{array}$ & $=3.000 \mathrm{ha}$ & $\begin{array}{l}\text { a. Berpotensi mengakibatkan perubahan } \\
\text { pola iklim mikro dan ekosistem kawasan, } \\
\text { mobilisasi tenaga kerja yang signifikan } \\
\text { pada daerah sekitarnya, pembebasan } \\
\text { lahan yang besar berpotensi } \\
\text { menimbulkan dampak sosial } \\
\text { b. Berpotensi menimbulkan dampak } \\
\text { perubahan ekosistem kawasan, bangunan } \\
\text { tambahan berpotensi mengubah } \\
\text { ekosistem yang ada. mobilisasi manusia } \\
\text { menimbulkan dampak social, perubahan } \\
\text { neraca air }\end{array}$ \\
\hline & $\begin{array}{l}\text { c. Pencetakan sawah, luas } \\
\text { (perkelompok) }\end{array}$ & $>500$ ha & $\begin{array}{l}\text { c. Memerlukan alat berat dalam jumlah } \\
\text { yang cukup banyak, Perubahan Tata Air. }\end{array}$ \\
\hline 7 & $\begin{array}{l}\text { Pembangunan Pengaman Pantai } \\
\text { dan perbaikan muara sungai: } \\
\text { - Jarak dihitung tegak lurus } \\
\text { pantai }\end{array}$ & $>500 \mathrm{~m}$ & $\begin{array}{l}\text { Berpotensi mengubah ekologi kawasan } \\
\text { pantai dan muara sungai sehingga } \\
\text { berdampak terhadap keseimbangan } \\
\text { ekosistem yang ada. Gelombang pasang laut } \\
\text { (tsunami) di Indonesia berpotensi } \\
\text { menjangkau kawasan sepanjang } 500 \text { m dari } \\
\text { tepi pantai, sehingga diperlukan kajian } \\
\text { khusus }\end{array}$ \\
\hline 8 & $\begin{array}{l}\text { Normalisasi Sungai } \\
\text { (termasuk sodetan) dan } \\
\text { Pembuatan Kanal Banjir } \\
\text { a. Kota besar/metropolitan } \\
\quad \text { - Panjang, atau } \\
\quad \text { - Volume pengerukan } \\
\text { b. Kota sedang } \\
\quad \text { - Panjang, atau }\end{array}$ & $\begin{array}{l}>5 \mathrm{~km} \\
>500.000 \mathrm{~m} 3 \\
>10 \mathrm{~km}\end{array}$ & $\begin{array}{l}\text { Terjadi timbunan tanah galian di kanan kiri } \\
\text { sungai yang menimbulkan dampak } \\
\text { lingkungan, dampak sosial, dan gangguan. } \\
\text { Mobilisasi alat besar dapat } \\
\text { Menimbulkan gangguan dan dampak. } \\
\text { Perubahan hidrologi dan pengaliran air hujan } \\
\text { (run - off) }\end{array}$ \\
\hline
\end{tabular}




\begin{tabular}{|c|c|c|c|}
\hline No & Jenis Kegiatan & $\begin{array}{l}\text { Skala/ } \\
\text { Besaran }\end{array}$ & Alasan Ilmiah Khusus \\
\hline & $\begin{array}{l}\text { - Volume pengerukan } \\
\text { c. Pedesaan } \\
\text { - Panjang, atau } \\
\text { - Volume pengerukan }\end{array}$ & $\begin{array}{l}>500.000 \mathrm{~m} 3 \\
>15 \mathrm{~km} \\
>500.000 \mathrm{~m} 3\end{array}$ & \\
\hline \multirow[t]{3}{*}{9} & $\begin{array}{l}\text { Pembangunan dan/atau } \\
\text { peningkatan jalan tol yang } \\
\text { membutuhkan pengadaan lahan } \\
\text { diluar rumija (ruang milik jalan) } \\
\text { dengan skala/besaran panjang } \\
\text { (km) dan skala/besaran luas } \\
\text { pengadaan lahan (ha): } \\
\text { a. di kota metropolitan/besar } \\
\text { panjang jalan dengan luas } \\
\text { lahan pengadaan lahan; atau } \\
\text { Luas pengadaan lahan }\end{array}$ & $\begin{array}{l}=5 \mathrm{~km} \\
\text { dengan } \\
\text { pengadaan } \\
\text { lahan }>10 \mathrm{ha} \\
30 \mathrm{ha}\end{array}$ & $\begin{array}{l}\text { a. Luas wilayah kegiatan operasi produksi } \\
\text { berkorelasi dengan luas penyebaran } \\
\text { dampak. Memicu alih fungsi lahan } \\
\text { beririgrasi teknis menjadi lahan } \\
\text { permukiman dan industry. Bangkitan lalu } \\
\text { lintas, dampak kebisingan getaran, emisi } \\
\text { yang tinggi, } \\
\text { gangguan visual dan dampak social }\end{array}$ \\
\hline & $\begin{array}{l}\text { b. di kota sedang } \\
\text { panjang jalan dengan luas } \\
\text { lahan pengadaan lahan; atau } \\
\text { Luas pengadaan lahan }\end{array}$ & $\begin{array}{l}=5 \mathrm{~km} \\
\text { dengan } \\
\text { pengadaan } \\
\text { lahan }>20 \mathrm{ha} \\
=30 \mathrm{ha}\end{array}$ & $\begin{array}{l}\text { b. Bangkitan lalu lintas, dampak kebisingan } \\
\text { getaran, emisi yang tinggi, gangguan } \\
\text { visual dan dampak social, alih fungsi } \\
\text { lahan }\end{array}$ \\
\hline & $\begin{array}{l}\text { c. di pedesaan } \\
\text { panjang jalan dengan luas } \\
\text { lahan pengadaan lahan; atau } \\
\text { Luas pengadaan lahan }\end{array}$ & $\begin{array}{l}=5 \mathrm{~km} \\
\text { dengan } \\
\text { pengadaan } \\
\text { lahan }>30 \mathrm{ha} \\
=40 \mathrm{ha}\end{array}$ & $\begin{array}{l}\text { c. Bangkitan lalu lintas, dampak kebisingan } \\
\text { getaran, emisi yang tinggi, gangguan } \\
\text { visual dan dampak social, alih fungsi } \\
\text { lahan }\end{array}$ \\
\hline 10 & $\begin{array}{l}\text { Pembangunan dan/atau } \\
\text { peningkatan jalan dengan } \\
\text { pelebaran yang membutuhkan } \\
\text { pengadaan lahan (di luar } \\
\text { rumija): } \\
\text { a. Di kota metropolitan/besar } \\
\text { b. D kota sedang } \\
\text { c. Pedesaan }\end{array}$ & $\begin{array}{l}\text { Skala/ besaran } \\
\text { idem uraian } \\
\text { jalan tol diatas }\end{array}$ & $\begin{array}{l}\text { Bangkitan lalu lintas, dampak kebisingan, } \\
\text { getaran, emisi yang tinggi, gangguan visual } \\
\text { dan dampak sosial }\end{array}$ \\
\hline 11 & $\begin{array}{l}\text { Persampahan } \\
\text { a. Pembangunana TPA sampah } \\
\text { domestikdengan system } \\
\text { controlled landfill / sanitary } \\
\text { landfill termasuk instalasi } \\
\text { penunjangnya } \\
\text {-luas kawasan TPA, atau } \\
\text {-kapasitas total }\end{array}$ & $\begin{array}{l}>10 \mathrm{ha} \\
=100.000 \text { ton }\end{array}$ & $\begin{array}{l}\text { a. Penyesuaian terhadap luas kawasan TPA } \\
\text { dengan daya tampung TPA. Perubahan } \\
\text { paradigma dari tempat } \\
\text { pembuangan/penampungan akhir menjadi } \\
\text { tempat pengolahan akhir. UU 18/2008 } \\
\text { tentang pengelolaan sampah dimana } \\
\text { konsep 3R menjadi bagian deskripsi } \\
\text { kegiatan Amdal TPA. Bukan lagi “open } \\
\text { dumping" tapi sebagi tempat pengolahan }\end{array}$ \\
\hline
\end{tabular}




\begin{tabular}{|c|c|c|c|}
\hline No & Jenis Kegiatan & $\begin{array}{l}\text { Skala/ } \\
\text { Besaran } \\
\end{array}$ & Alasan Ilmiah Khusus \\
\hline & $\begin{array}{l}\text { b. TPA di daerah pasang surut - } \\
\text { luas landfill, atau } \\
\text {-kapasitas total }\end{array}$ & $\begin{array}{l}\text { Semua } \\
\text { kapasitas / } \\
\text { besaran }\end{array}$ & $\begin{array}{l}\text { akhir, sehingga ada composting dan } \\
\text { landfill gas (waste to energy) untuk } \\
\text { incinerator biasanya untuk kapasitas yang } \\
\text { kecil (<100 ton per hari) prosesnya kurang } \\
\text { sempurna sehingga dampaknya dapat } \\
\text { lebih penting } \\
\text { b. Pengaturan TPA ini lebih ketat dari pada } \\
\text { di wilayah lain. Secara teknis, daerah } \\
\text { pasang surut tidak direkomendasikan } \\
\text { untuk menjadi lahan TPA. Tetapi untuk } \\
\text { beberap wilayah yang tidak punya pilihan } \\
\text { wilayah lain maka tetap dapat } \\
\text { diperbolehkan membangun TPA di daerah } \\
\text { pasang surut }\end{array}$ \\
\hline & $\begin{array}{l}\text { c. Pembangunan transfer } \\
\text { station-kapasitas }\end{array}$ & 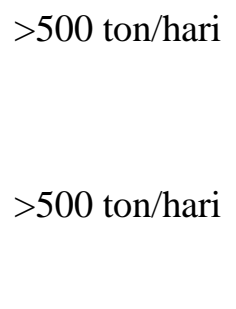 & $\begin{array}{l}\text { c. Lokasi transfer station pada umumnya } \\
\text { terletak di dalam atau di pinggiran kota } \\
\text { dan dibangun pada luas lahan yang } \\
\text { terbatas } \\
\text { d. Guna mendorong minat swasta/ } \\
\text { masyarakat }\end{array}$ \\
\hline & $\begin{array}{l}\text { d. Pembangunan instalasi } \\
\text { pengolahan sampah terpadu- } \\
\text { kapasitas } \\
\text { e. Pengolahan dengan } \\
\text { insinerator- kapasitas }\end{array}$ & $\begin{array}{l}\text { Semua } \\
\text { kapasitas }\end{array}$ & $\begin{array}{l}\text { e. Pengolahan sampah domestik berapapun } \\
\text { kapasitasnya harus dilengkapi dengan } \\
\text { amdal karena saat ini sampah domestic } \\
\text { masih tercampur dengan limbah B3 } \\
\text { f. Kapasitas composting plant diperbesar } \\
\text { untuk mendorong minat swasta / } \\
\text { masyarakat dalam komposting }\end{array}$ \\
\hline 12 & $\begin{array}{l}\text { Air Limbah Domestik } \\
\text { a. Pembangunan Instalasi } \\
\text { Pengolahan Lumpur Tinja } \\
\text { (IPLT), termasuk fasilitas } \\
\text { penunjangnya } \\
\text { - Luas, atau } \\
\text { - Kapasitasnya } \\
\text { b. Pembangunan Instalasi } \\
\text { Pengolahan Air Limbah } \\
\text { (IPAL) domestik termasuk } \\
\text { fasilitas penunjangnya }\end{array}$ & $\begin{array}{l}>3 \text { ha } \\
>2,4 \text { ton/hari }\end{array}$ & $\begin{array}{l}\text { a. Setara dengan layanan untuk } 100.000 \\
\text { orang.Dampak potensial berupa bau, } \\
\text { gangguan kesehatan, lumpur sisa yang } \\
\text { tidak diolah dengan baik dan gangguan } \\
\text { visual. }\end{array}$ \\
\hline
\end{tabular}




\begin{tabular}{|c|c|c|c|}
\hline No & Jenis Kegiatan & $\begin{array}{l}\text { Skala/ } \\
\text { Besaran }\end{array}$ & Alasan Ilmiah Khusus \\
\hline & $\begin{array}{l}\text { - Luas, atau } \\
\text { - Beban organik } \\
\text { c. Pembangunan sistem } \\
\text { perpipaan air limbah, luas } \\
\text { layanan, atau } \\
\text {-Luas layanan, atau } \\
\text {-Debit air limbah }\end{array}$ & $\begin{array}{l}>500 \text { ha } \\
>16.000 \\
\mathrm{~m}^{3} / \mathrm{hari}\end{array}$ & $\begin{array}{l}\text { c. Setara dengan layanan } 100.000 \text { orang. } \\
\text { Setara dengan } 20.000 \text { unit sambungan air } \\
\text { limbah. Dampak potensial berupa } \\
\text { gangguan lalu lintas, kerusakan prasarana } \\
\text { umum, ketidaksesuaian atau nilai } \\
\text { kompensasi }\end{array}$ \\
\hline 13 & $\begin{array}{l}\text { Pembangunan saluran drainase } \\
\text { (primer dan/atau sekunder) di } \\
\text { permukiman } \\
\text { a. Kota besar/ metropolitan } \\
\quad \text { panjang } \\
\text { b.Kota sedang, panjang }\end{array}$ & $\begin{array}{l}>5 \mathrm{~km} \\
>10 \mathrm{~km}\end{array}$ & $\begin{array}{l}\text { Berpotensi menimbulkan ganggun lalu lintas } \\
\text { kerusakan prasarana dan sarana umum, } \\
\text { pencemaran di daerah hilir, perubahan tata } \\
\text { air di sekitar jaringan, pertambahan aliran } \\
\text { puncak dan perubahan perilaku masyarakat } \\
\text { di sekitar jaringan. Pembangunan drainase } \\
\text { sekunder di kota sedang yang melewati } \\
\text { permukiman padat }\end{array}$ \\
\hline 14 & $\begin{array}{l}\text { Jaringan air bersih di kota besar / } \\
\text { metropolitan } \\
\text { a. Pembangunan jaringan } \\
\text { distribusi-Luas layanan } \\
\text { b. Pembangunan jaringan } \\
\text { transmisi-panjang }\end{array}$ & $\begin{array}{l}>500 \mathrm{ha} \\
>10 \mathrm{~km}\end{array}$ & $\begin{array}{l}\text { Berpotensi menimbulkan dampak hidrologi } \\
\text { dan persoalan keterbatasan air } \\
\text { Konflik sosial pemakaian air di sepanjang } \\
\text { jaringan pipa }\end{array}$ \\
\hline 15 & $\begin{array}{l}\text { Pembangunan Perumahan dan } \\
\text { kawasan Permukimam dengan } \\
\text { pengelola tertentu: } \\
\text { a. Kota Metropolitan, luas } \\
\text { b. Kota besar, luas } \\
\text { c. Kota sedang dan kecil, luas } \\
\text { d. Untuk keperluan settlement } \\
\text { transmigrasi }\end{array}$ & $\begin{array}{l}>25 \mathrm{ha} \\
>50 \mathrm{ha} \\
>100 \mathrm{ha}\end{array}$ & $\begin{array}{l}\text { Analisis teknis,melipui: Tingkat pembebasan } \\
\text { lahan, Daya dukung lahan, seperti daya } \\
\text { dukung tanah, kapasitas resapan air tanah, } \\
\text { tingkat kepadatan bangunan per-hektar, } \\
\text { Tingkat kebutuhan ar seharai-hari, Limbah } \\
\text { yang dihasilkan sebagai akibat hasil kegiatan } \\
\text { perumahan dan permukimn, Efek } \\
\text { pembanguan terhadap lingkungan sekitar } \\
\text { (mobilisasi material, manusia, dan lalu } \\
\text { lintas), KDB (Koefisien dasar bangunan) dan } \\
\text { KLB (koefisien luas bangunan), Peningkatan } \\
\text { air larian (run-off) yang mengakibatkan } \\
\text { banjir dihilirnya. }\end{array}$ \\
\hline 16 & $\begin{array}{l}\text { Reklamasi wilayah Pesisir dan } \\
\text { Pulau-pulau Kecil, dengan } \\
\text { a. Luas area reklamasi } \\
\text { b. Volume material urug, atau } \\
\text { c. Panjang reklamasi }\end{array}$ & $\begin{array}{l}>25 \mathrm{ha} \\
>500.000 \mathrm{~m}^{3} \\
>50 \mathrm{~m} \text { (tegak } \\
\text { lurus ke arah } \\
\text { laut dan garis } \\
\text { pantai }\end{array}$ & $\begin{array}{l}\text { Berpotensi menimbulkan dampak } \\
\text { a. Hidrooseanografi, meliputi pasang surut, } \\
\text { arus, gelombang dan sedimen dasar laut } \\
\text { b. Hidrologi, meliputi curah hujan, air tanah, } \\
\text { debit air sungai atau saluran, dan air } \\
\text { limpasan. } \\
\text { c. Batimetri, meliputi kontur kedalaman } \\
\text { dasar perairan } \\
\text { d. Topografi, meliputi kontur permukaan }\end{array}$ \\
\hline
\end{tabular}




\begin{tabular}{|c|c|c|c|}
\hline No & Jenis Kegiatan & $\begin{array}{l}\text { Skala/ } \\
\text { Besaran } \\
\end{array}$ & Alasan Ilmiah Khusus \\
\hline & & & $\begin{array}{l}\text { daratan } \\
\text { e. Geomorfologi, meliputi bentuk dan } \\
\text { tipologi pantai } \\
\text { f. Geoteknik, meliputi sifat-sifat fisis dan } \\
\text { mekanis lapisan tanah } \\
\text { g. Dampak sosial }\end{array}$ \\
\hline 17 & $\begin{array}{l}\text { Pemotongan bukit dan } \\
\text { pengurugan lahan dengan } \\
\text { Volume }\end{array}$ & $>500.000 \mathrm{~m}^{3}$ & $\begin{array}{l}\text { a. Mengubah bentang alam } \\
\text { b. Longsor dan peningkatan run-off dan } \\
\text { banjir }\end{array}$ \\
\hline 18 & $\begin{array}{l}\text { Pengambilan air bersih dari } \\
\text { danau, sungai, mata air, atau } \\
\text { sumber air permukaan lainnya } \\
\text { - Debit } \\
\text { - pengambilan }\end{array}$ & $\begin{array}{l}>2501 / \text { detik, } \\
\text { ini setara } \\
\text { dengan } \\
\text { kebutuhan air } \\
\text { bersih } 250.000 \\
\text { orang }\end{array}$ & $\begin{array}{l}\text { Kalau berdasarkan kapasitas } 250 \text { l/detik, itu } \\
\text { setara dengan (sambungan ke pelanggan) } \\
250.000 \text { orang dengan asumsi } 1 \text { lt/det/orang } \\
\text { atau } 86,4 \text { lt/orang/hari, dengan asumsi per } \\
\text { SL untuk } 6 \text { orang, akan memenuhi kebutuhsn } \\
250.000 \text { penduduk, Potensi konflik } \\
\text { penggunaan air dengan pengguna air lainnya, } \\
\text { gangguan neraca air }\end{array}$ \\
\hline 19 & $\begin{array}{l}\text { Pengambilan air bawah tanah } \\
\text { (sumur tanah dangkal, sumur } \\
\text { tanah dalam) }\end{array}$ & $\begin{array}{l}>50 \text { liter/detik } \\
\text { (dari satu atau } \\
\text { beberapa } \\
\text { sumur pada } \\
\text { kawasan }<10 \\
\text { ha }\end{array}$ & $\begin{array}{l}\text { Potensi gangguan terhadap kondisi } \\
\text { lingkungan, antara lain amblesan tanah (land } \\
\text { subsidence), intrusi air laut/asin (salt water } \\
\text { intrusion) dan kekeringan terhadap sumur } \\
\text { bor dangkal/gali yang dipergunakan } \\
\text { masyarakat sekitar. }\end{array}$ \\
\hline 20 & $\begin{array}{l}\text { Pembangunan bangunan gedung } \\
\text { - luas lahan, atau } \\
\text { - bangunan }\end{array}$ & $\begin{array}{l}>5 \mathrm{ha} \\
>10.000 \mathrm{~m}^{2}\end{array}$ & $\begin{array}{l}\text { Besaran diperhitungkan berdasarkan: } \\
\text { a. Pembebasan lahan } \\
\text { b. Daya dukung lahan } \\
\text { c. Tingkat kebutuhan air sehari-hari } \\
\text { d. Limbah yang dihaslkan } \\
\text { e. Efek terhadap lingkungan sekitar (getaran, } \\
\text { kebisingan, polusi udara, dan lain-lain) } \\
\text { f. KDB (koefisien dasar bangunan) dan } \\
\text { KLB (koefisien luas bangunan) } \\
\text { g. Jumlah dan jenis pohon yang mungkin } \\
\text { hilang } \\
\text { h. Konflik sosial akibat pembebasan lahan } \\
\text { (umumnya berlokasi dekat pusat kota } \\
\text { yang memiliki kepadatan tinggi) } \\
\text { i. Struktur bangunan bertingkat tinggi dan } \\
\text { basement meyebabkan masalah } \\
\text { dewatering dan gangguan tiang-tiang } \\
\text { pancang terhadap akuifer sumber air } \\
\text { sekitar } \\
\text { j. Bangkitanpergerakan (traffic) dan } \\
\text { kebutuhan permukiman dari tenaga kerja }\end{array}$ \\
\hline
\end{tabular}




\begin{tabular}{lll}
\hline No Jenis Kegiatan & $\begin{array}{l}\text { Skala/ } \\
\text { Besaran }\end{array}$ & Alasan Ilmiah Khusus \\
\hline & & yang besar. \\
& k. Bangkitan pergerakan dan kebutuhan \\
& parkir pengunjung. \\
& 1. Produksi sampah, limbah domestik \\
& m. Genangan/banjir lokal \\
\hline
\end{tabular}

Berdasarkan Tabel 1 diatas, kegiatan manajemen aset infrastruktur dan fasilitasnya merupakan kegiatan yang menimbulkan dampak lingkungan pada komponen lingkungan fisik-kimia, biologi, sosekbud, dan kesmas, sehingga setiap rencana kegiatan yang menyangkut manajemen aspek infrastruktr dan fasilitasnya secara umum perlu menyusun amdal untuk yang masuk kategori penting dan menyusun UKL-UPL untuk yang tidak berdampak penting, yang skala/besaran lebih kecil dari skala/besaran untuk amdal. Jenis kegiatan yang wajib UKL-UPL umumnya ditetapkan dengan keputusan Gubernur. Tim penyusun studi amdal yang telah memenuhi persyaratan kompetensi minimal 1 KTPA (Ketua Tim Penyusun Amdal) dan 2 ATPA (Anggota Tim Penyusun Amdal) akan menyusun dokumen KA-Andal, Andal, RKL-RPL dengan mengacu ke PermenLH 16/2012 dan teori dari literatur yang terkait (Pischke F. \& Cashmor M., 2006; Fandeli, 2000; Mariott, B.B.,1997). Dokumen KA-Andal dinilai oleh Komisi Penilai Amdal (KPA) yang sudah mempunyai lisensi. Penilaian amdal juga umum dilakukan di banyak negara (Sandham L.A et al, 2011; Runhaar H et al, 2012; Panigrahi J.K \& Amirapu S., 2012), Dokumen Andal, RKL-RPL yang disusun berdasarkan KA-Andal juga dinilai oleh Komisi Penilai Amdal sebelum diterbitkan surat keputusan kelayakan lingkungan hidup (SKKLH) dan Izin Lingkungan. Memang harus diakui tidak semua dokumen amdal mutunya bagus (Heinma K \& Poder T, 2010), termasuk di Indonesia. Peran para pakar dalam Komisi Penilai Amdal (KPA) ssngat menentukan kualitas dari dokumen amdal.

\section{b. Kegiatan yang sudah dan sedang berlangsung (tahap operasi)}

Sampai tahun 2018 masih banyak Infrastruktur dan Fasilitasnya yang sudah beroperasi di Indonesia yang belum mempunyai Izin Lingkungan karena belum mempunyai dokumen lingkungan baik berupa dokumen amdal maupun dokumen UKLUPL. Dokumen lingkungan mempunyai peranan penting untuk dapat menanggulangi dan memantau dampak lingkungan yang ditimbulkan oleh kegiatan Infrastruktur dan Fasilitasnya. Karena sudah memasuki tahap operasi, maka dampak lingkungan yang terjadi umumnya sudah bisa diukur besar dan pentingnya. Oleh sebab itu sistimatika dokumen lingkungan untuk kegiatan yang sudah beroperasi berbeda dengan dokumen lingkungan untuk kegiatan yang masih dalam taraf rencana. Metode evaluasi dampak pada kegiatan yang sudah dan sedang berlangsung ini dikenal sebagai metode Audit Lingkungan. Untuk kegiatan yang masuk kategori amdal, perlu menyusun DELH (Dokumen Evaluasi Lingkungan Hidup) dan untuk kegiatan yang masuk kaegori UKLUPL perlu menyusun DPLH (Dokumen Pengelolaan Lingkungan Hidup). Rujukan untuk penyusunan kedua jenis dokumen ini mengacu ke Peraturan Menteri Lingkungan Hidup Kehutanan No P.102/2016.

\section{Rencana pengelolaan dan pemantauan dampak lingkungan}

Menurut Peraturan Menteri Lingkungan Hidup 16/2012 Rencana Pengelolaan Lingkungan Hidup selanjutnya disebut RKL adalah upaya penanganan dampak lingkungan yang ditimbulkan dari rencana usaha dan/atau kegiatan, sedangkan Rencana Pemantauan Lingkungan Hidup selanjutnya disebut RPL adalah upaya pemantauan komponen lingkungan hidup yang terkena dampak dari rencana usaha dan/atau kegiatan. RKL-RPL 
harus memuat mengenai upaya untuk menangani dampak dan memantau komponen lingkungan hidup yang terkena dampak terhadap keseluruhan dampak, bukan hanya dampak yang disimpulkan sebagai dampak penting dari hasil proses evaluasi holistik dalam Andal, namun juga untuk beberapa dampak yang disimpulkan sebagai bukan dampak penting, namun tetap memerlukan dan direncanakan untuk dikelola dan dipantau (dampak lingkungan hidup lainnya), maka tetap perlu disertakan rencana pengelolaan dan pemantauannya dalam RKL-RPL, seperti diperlihatkan di Gambar1.

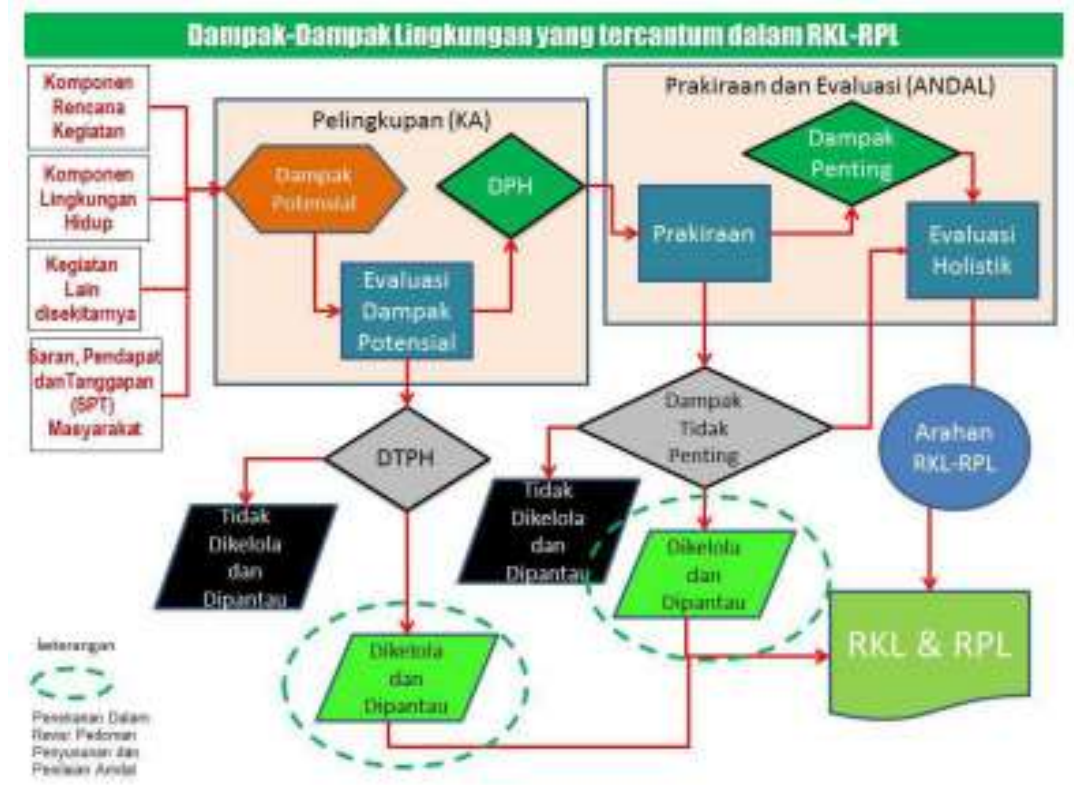

Gambar 1. Dampak-dampak lingkungan yag tercantum dalam RKL-RPL (Anonim, 2012c)

\section{Lingkup rencana pengelolaan lingkungan hidup}

RKL memuat upaya-upaya mencegah, mengendalikan dan menanggulangi dampak penting lingkungan hidup dan dampak lingkungan hidup lainnya yang bersifat negatif dan meningkatkan dampak positif yang timbul sebagai akibat dari suatu rencana usaha dan/atau kegiatan. Dalam pengertian tersebut upaya pengelolaan lingkungan hidup antara lainmencakup kelompok aktivitas sebagai berikut:

a. Pengelolaan lingkungan yang bertujuan untuk menghindari atau mencegah dampak negatif lingkungan hidup;

b. Pengelolaan lingkungan hidup yang bertujuan untuk menanggulangi, meminimisasi, atau mengendalikan dampak negatif baik yang timbul pada saat usaha dan/atau kegiatan; dan/atau

c. Pengelolaan lingkungan hidup yang bersifat meningkatkan dampak positif sehingga dampak tersebut dapat memberikan manfaat yang lebih besar baik kepada pemrakarsa maupun pihak lain terutama masyarakat yang turut menikmati dampak positif tersebut.

Untuk menangani dampak penting yang sudah diprediksi dari studi Andal dan dampak lingkungan hidup lainnya, pengelolaan lingkungan hidup yang dirumuskan dapat menggunakan salah satu atau beberapa pendekatan lingkungan hidup yang selama ini dikenal seperti: teknologi, sosial ekonomi, maupun institusi.

\section{Lingkup rencana pemantauan lingkungan hidup}

Pemantauan lingkungan hidup dapat digunakan untuk memahami fenomenafenomena yang terjadi pada berbagai tingkatan, mulai dari tingkat proyek (untuk memahami perilaku dampak yang timbul akibat usaha dan/atau kegiatan), sampai ke tingkat kawasan atau 
bahkan regional; tergantung pada skala masalah yang dihadapi. Pemantauan merupakan kegiatan yang berlangsung secara terus-menerus, sistematis dan terencana.Pemantauan dilakukan terhadap komponen lingkungan yang relevan untuk digunakan sebagai indikator untuk mengevaluasi penaatan (compliance), kecenderungan ( trendline) dan tingkat kritis (critical level) dari suatu pengelolaan lingkungan hidup. Ada beberapa faktor yang perlu diperhatikan dalam merumuskan rencana pemantauan lingkungan dalam Dokumen RKLRPL, yakni :

a. Komponen/parameter lingkungan hidup yang dipantau mencakup komponen/parameter lingkungan hidup yang mengalami perubahan mendasar, atau terkena dampak penting dan komponen/parameter lingkungan hidup yang terkena dampak lingkungan hidup lainnya.

b. Aspek-aspek yang dipantau perlu memperhatikan benar dampak penting yang dinyatakan dalam Andal dan dampak lingkungan hidup lainnya, dan sifat pengelolaan dampak lingkungan hidup yang dirumuskan rencana pengelolaan lingkungan hidup.

c. Pemantauan dapat dilakukan pada sumber penyebab dampak dan/atau terhadap komponen/parameter lingkungan hidup yang terkena dampak. Dengan memantau kedua hal tersebut sekaligus akan dapat dinilai/diuji efektivitas kegiatan pengelolaan lingkungan hidup yang dijalankan.

d. Pemantauan lingkungan hidup harus layak secara ekonomi. Biaya yang dikeluarkan untuk pemantauan perlu diperhatikan mengingat kegiatan pemantauan senantiasa berlangsung sepanjang usia usaha dan/atau kegiatan.

e. Rencana pengumpulan dan analisis data aspek-aspek yang perlu dipantau, mencakup:

1. jenis data yang dikumpulkan;

2. lokasi pemantauan;

3. frekuensi dan jangka waktu pemantauan;

4. metode pengumpulan data (termasuk peralatan dan instrumen yang digunakan untuk pengumpulan data);

5. metode analisis data.

f. Rencana pemantauan lingkungan perlu memuat tentang kelembagaan pemantauan lingkungan hidup. Kelembagaan pemantauan lingkungan hidup yang dimaksud di sini adalah institusi yang bertanggungjawab sebagai pelaksana pemantauan, pengguna hasil pemantauan, dan pengawas kegiatan pemantauan.

Pelaksanan RKL dan RPL dari amdal atau DELH perlu dilaporkan dengan membuat pelaporan setiap 6 bulan sekali ke Dinas Lingkungan Hidup di Kabupaten/Kota/Propinsi atau ke Kementerian Lingkungan Hidup disesuaikan dengan kewenangannya masing-masing. Demikian juga untuk pelaksanaan UKL-UPL atau DPLH perlu dilaporkan dengan membuat pelaporan setiap 6 bulan sekali ke Dinas Lingkungan Hidup di Kabupaten/Kota/Propinsi atau ke Kementerian Lingkungan Hidup disesuaikan dengan kewenangannya masing-masing. Ketentuan tentang pelaporan oleh pemrakarsa kegiatan setiap 6 bulan sekali ini sudah tertuang dalam KepmenLH No 45/2005 (Anonim, 2005) seperti juga dilakukan dibanyak negara (Annandale \& Taplin, 2003; Branis \& Christopoulos, 2005).

\section{KESIMPULAN}

Pemikiran mengenai aspek lingkungan bagi manajemen aset infrastruktur bisa disimpulkan sebagai berikut.

1. Kegiatan manajemen aset infrastruktur dan fasilitasnya merupakan kegiatan yang secara umum menimbulkan dampak lingkungan sehingga setiap rencana kegiatan yang menyangkut manajemen aspek infrastruktur dan fasilitasnya perlu menyusun amdal atau 
UKL-UPL sesuai dengan penting atau tidaknya dampak lingkungan yang akan ditimbulkannya.

2. Untuk kegiatan manajemen aset infrastruktur dan fasilitasnya yang sudah beroperasi tapi belum memiliki izin lingkungan, sesuai regulasi yang berlaku, masih perlu menyusun DELH (Dokumen Evaluasi Lingkungan Hidup) atau DPLH (Dokumen Pengelolaan Lingkungan Hidup) sesuai dengan penting tidaknya dampak lingkungan yang sudah dan sedang berlangsung.

3. Pelaksanan RKL dan RPL dari dokumen amdal atau DELH perlu dilaporkan dengan membuat pelaporan setiap 6 bulan sekali ke Dinas Lingkungan Hidup di Kabupaten/Kota/Propinsi atau ke Kementerian Lingkungan Hidup disesuaikan dengan kewenangannya masing-masing.

4. Pelaksanaan UKL-UPL atau DPLH perlu dilaporkan dengan membuat pelaporan setiap 6 bulan sekali ke Dinas Lingkungan Hidup di Kabupaten/Kota/Propinsi atau ke Kementerian Lingkungan Hidup disesuaikan dengan kewenangannya masing-masing.

Pemikiran ini perlu dilanjutkan dengan pemikiran identitas bentuk - bentuk kaitan antara infrastruktur dengan aspek lingkungan.

\section{DAFTAR PUSTAKA}

Alshuwaikhat, Habib M. (2005). "Stategic environmental assessment can help solve environmental impact assessment failures in developing countries". Environmental Impact Assesment Review, 25(4), 307-317. doi: http://dx.doi.org/10/1016/j.eiar.2004.09.003.

Annandale, David, \& Taplin, Ross. (2003). "Is environmental impact assessment regulation a 'burden' to private firms?” Environmental Impact Assessment Review, 23(3), 383-397. doi: http://dx.doi.org/10.1016/S0195-9255(03)00002-7.

Anonim. (2005). Keputusan Menteri Negara Lingkungan Hidup Nomor 45 tahun 2005 tentang Pedoman Penyusunan Laporan Pelaksanaan Rencana Pengelolaan Lingkungan Hidup (RKL) dan Rencana Pemantauan Lingkungan Hidup (RPL).

Anonim. (2009). Undang-undang Rebulik Indonesia Nomor 32 tahun 2009 tentang Perlindungan dan Pengelolaan Lingkungan Hidup. Lembaran Negara Republik Indonesia Tahun 2009 Nomor 140. Jakarta. http://www.menlh.go.id

Anonim. (2011). Peraturan Menteri Negara Lingkungan Hidup Republik Indonesia Nomor 13 tahun 2011 tentang Ganti Kerugian kibat Pencemaran dan/atau Kerusakan Lingkugan Hidup. Berita Negara Republik Indonesia Tahun 2011. Jakarta. http://www.menlh.go.id

Anonim.(2012a). Peraturan Pemerintah Republik Indonesia Nomor 27 tahun 2012 tentang Izin Lingkungan. Lembaran Negara Republik Indonesia Tahun 2012 Nomor 48. Jakarta. http://www.menlh.go.id

Anonim. (2012b). Peraturan Menteri Negara Lingkungan Hidup Republik Indonesia Nomor 5 tahun 2012 tentang jenis rencana usaha atau kegiatan yang wajib memiliki Analisis Mengenai Dampak Lingkungan Hidup. Berita Negara Republik Indonesia Tahun 2012 Nomor 408. Jakarta. http://www.menlh.go.id

Anonim. (2012c). Peraturan Menteri Negara Lingkungan Hidup Republik Indonesia Nomor 16 tahun 2012 tentang Pedoman Penyusunan Dokumen Lingkungan. Berita Negara Republik Indonesia Tahun 2012 Nomor 990. Jakarta. http://www.menlh.go.id

Anonim. (2012d). Peraturan Menteri Negara Lingkungan Hidup Republik Indonesia Nomor 17 tahun 2012 tentang Pedoman Keterlibatan Masyarakat dalam Proses Analisis Dampak Lingkungan Hidup dan Izin Lingkungan. Berita Negara Republik Indonesia Tahun 2012 Nomor 991. Jakarta. http://www.menlh.go.id 
BSN (2015). Sistem Manajemen Lingkungan, Persyaratan dengan panduan penggunaan, SNI ISO 14001:2015. Badan Standarisasi Nasional.

Braniš, M., \& Christopoulos, S. (2005). Mandated monitoring of post-project impacts in the Czech EIA. Environmental Impact Assessment Review, 25(3), 227-238.

Fandeli, C. (2000). Analisis Mengenai Dampak Lingkungan Prinsip Dasar dan Pemapanannya dalam Pembangunan. Penerbit Liberty. Yogyakarta

Hartley, N., \& Wood, C. (2005). "Public participation in environmental impact assessmentimplementing the Aarhus Convention". Environmental Impact Assessment.

Heinma, K., \& Põder, T. (2010). Effectiveness of Environmental Impact Assessment system in Estonia. Environmental Impact Assessment Review, 30(4), 272-277. doi: http://dx.doi.org/10.1016/j.eiar.2009.10.001.

Hourdequin, M., Landres, P., H., Mark J., \& Craig, D. R. (2012). Ethical implications of democratic theory for U.S. public participation in environmental impact assessment. Environmental Impact Assessment Review, 35(0), 37-44. doi: http://dx.doi.org/10.1016/j.eiar.2012.02.001.

Jarvis, A. P., \& Younger, P. L. (2000). Broadening the scope of mine water environmental impact assessment: a UK perspective. Environmental Impact Assessment Review, 20(1), 85-96. doi: http://dx.doi.org/10.1016/S0195-9255(99)00032-3.

Jay, S., Jones, C., Slinn, P, \& Wood, C. (2007). Environmental impact assessment: Retrospect and prospect. Environmental Impact Assessment Review, 27(4), 287-300. doi: http://dx.doi.org/10.1016/j.eiar.2006.12.001Review, 25(4), 319-340. doi: http://dx.doi.org/10.1016/j.eiar.2004.12.002.

Mariott, B.B. (!997). Practical Guide to Environmental Impact Assessment. The McGraw-Hill Companies. New York.

Momtaz, S. (2002). Environmental impact assessment in Bangladesh: A critical review. Environmental Impact Assessment Review, 22(2), 163-179. doi: http://dx.doi.org/10.1016/S0195-9255(01)00106-8.

Nadeem, O., \& Hameed, R. (2008). Evaluation of environmental impact assessment system in Pakistan. Environmental Impact Assessment Review, 28(8), 562-571. doi: http://dx.doi.org/10.1016/j.eiar.2008.02.003.

O'Faircheallaigh, C. (2009). Public participation and environmental impact assessment: Purposes, implications, and lessons for public policy making. Environmental Impact Assessment Review, 30(1), 19-27. doi: http://dx.doi.org/10.1016/j.eiar.2009.05.001.

Opoku, A.S. (2001). Environmental impact assessment in developing countries: the case of Ghana. Environmental Impact Assessment Review, 21(1), 59-71. doi: http://dx.doi.org/10.1016/S0195-9255(00)00063-9.

Panigrahi, J. K., \& Amirapu, S. (2012). An assessment of EIA system in India. Environmental Impact Assessment Review, 35(0), 23-36. doi: http://dx.doi.org/10.1016/j.eiar.2012.01.005.

Pischke, F., \& Cashmore, M.. (2006). Decision-oriented environmental assessment: An empirical study of its theory and methods. Environmental Impact Assessment Review, 26(7), 643-662. doi: http://dx.doi.org/10.1016/j.eiar.2006.06.004.

Runhaar, H.V.L., Frank, D., P., \& Arts, J. (2012). Environmental assessment in The Netherlands: Effectively governing environmental protection? A discourse analysis. Environmental Impact Assessment Review, 39(0), 13-25. doi: http://dx.doi.org/10.1016/j.eiar.2012.05.003.

Saarikoski, H.. (2000). Environmental impact assessment (EIA) as collaborative learning process. Environmental Impact Assessment Review, 20(6), 681-700. doi: http://dx.doi.org/10.1016/S0195-9255(00)00059-7. 
Sandham, L. A., van Heerden, A. J., Jones, C. E., Retief, F. P., \& Morrison- S A. N. (2011). Does enhanced regulation improve EIA report quality? Lessons from South Africa. Environmental Impact Assessment Review, 38(0), 155-162. doi: http://dx.doi.org/10.1016/j.eiar.2012.08.001.

Soemitro, R.A.A. \& Suprayitno, H. (2018). "Pemikiran Awal tentang Konsep Dasar Manajemen Aset Fasilitas". Jurnal Manajemen Aset Infrastruktur \& Fasilitas, Vol. 2, Sup. 1, Juni 2018.

Suprayitno, H. \& Soemitro, R.A.A. (2018). "Preliminary Reflexion on Basic Principle of Infrastructure Asset Management". Jurnal Manajemen Aset Infrastruktur \& Fasilitas, Vol. 2, No. 1, Maret 2018.

Toro, J., Requena, I., \& Zamorano, M. (2009). Environmental impact assessment in Colombia: Critical analysis and proposals for improvement. Environmental Impact Assessment Review, 30(4), 247-261. doi: http://dx.doi.org/10.1016/j.eiar.2009.09.001

Yakin, A. (1997). Ekonomi Sumber Daya dan Lingkungan, Teori dan Kebijakan Pembangunan Berkelanjutan. Akademika Presindo. Jakarta. 
(e)ISSN 2615-1847 (p)ISSN 2615-1839

Jurnal Manajemen Aset Infrastruktur \& Fasilitas - Vol. 2, No. 2, September 2018 